\title{
Reactions of 1,4-bis(tetrazole)benzenes: formation of long chain alkyl halides
}

\author{
Andrew D. Bond, ${ }^{\mathrm{a}}$ Adrienne Fleming, ${ }^{\mathrm{b}}$ Fintan Kelleher, ${ }^{\mathrm{b}}$ John McGinley ${ }^{\mathrm{c}, *}$ and Vipa Prajapati ${ }^{\mathrm{b}}$

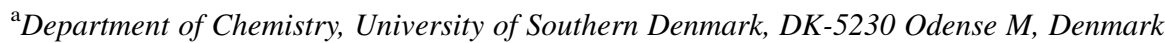 \\ ${ }^{\mathrm{b}}$ Department of Science and Advanced Smart Materials Research Center, Institute of Technology, Tallaght, Dublin 24, Ireland \\ ${ }^{\mathrm{c}}$ Department of Chemistry, National University of Ireland Maynooth, Maynooth, Co. Kildare, Ireland
}

Received 13 April 2006; revised 7 July 2006; accepted 27 July 2006

Available online 21 August 2006

\begin{abstract}
The reactions of 1,4-bis[2-(tributylstannyl)tetrazol-5-yl]benzene with $\alpha, \omega$-dibromoalkanes were carried out in order to synthesise pendant alkyl halide derivatives of the parent bis-tetrazole. This led to the formation of several alkyl halide derivatives, substituted variously at $\mathrm{N} 1$ or N2 on the tetrazole ring. The crystal structures of 1,4-bis[(2-(4-bromobutyl)tetrazol-5-yl)]benzene (2- N,2- $\left.N^{\prime}\right), 1,4$-bis[(2-(4-bromobutyl)tetrazol-5-yl)]benzene $\left(1-N, 2-N^{\prime}\right)$ and 1,4-bis[(2-(8-bromooctyl)tetrazol-5-yl)]benzene (2- $\left.N, 2-N^{\prime}\right)$ are reported. Further discussion involves the structure of 1,4-bis[2-(6-bromohexyl)-2H-tetrazol-5-yl]benzene $\left(2-N, 2-N^{\prime}\right)$ previously reported.

(C) 2006 Elsevier Ltd. All rights reserved.
\end{abstract}

\section{Introduction}

The synthesis of tetrazoles from a cycloaddition reaction between a nitrile and an azide is well documented ${ }^{1-6}$ since tetrazoles have roles in coordination chemistry as ligands, in medicinal chemistry as metabolically stable surrogates for carboxylic acids and in materials science applications, including photography and explosives. The interest in the ability of tetrazoles to mimic the carboxylic acid group has motivated the incorporation of tetrazoles into biologically active molecules. ${ }^{2}$ This potential use has led to the incorporation in therapeutic applications, including their incorporation in pharmacologically active compounds with anti-hypertensive, anti-allergic and antibiotic activities. ${ }^{3}$

In recent years, particular attention has been directed towards the use of polydentate aromatic nitrogen heterocycles, specifically ligands with five-membered rings (azoles). Among these, imidazoles and triazoles have been extensively used for their ability to construct open framework networks with a wide variety of topologies. Tetrazoles exhibit a strong networking ability usually acting as mono- or bidentate ligands in most of the reported complexes. ${ }^{7-9}$ A possible application for these materials as molecular hosts is in generating supramolecular arrays, which embody additional functional groups capable of metal complexation. This would result in a metallotetrazole framework with potential as new catalysts, anti-bacterial or therapeutic agents. Our

Keywords: Tetrazole; Organotin; X-ray; Alkyl halide; NMR spectroscopy.

* Corresponding author. Tel.: +353 1708 4615; fax: +353 1708 3815;

e-mail: john.mcginley@nuim.ie interest in macrocycles containing tetrazoles surrounds their use as precursors for the formation of new functionalised poly-tetrazoles as, for example, sensors or in molecular recognition.

Molloy et al., ${ }^{5}$ Butler and Fleming ${ }^{10}$ have synthesised bis(bromoalkyltetrazolyl)benzenes from either tributylstannylsubstituted bis-tetrazoles or $N$-unsubstituted tetrazoles with dihaloalkanes with the 2- $N, 2-N^{\prime}$-isomer again being the predominant product; Molloy et al. studied both the 1,2- and 1,3-substituted bis-tetrazole while Butler and Fleming looked only at the 1,3-unsubstituted bis-tetrazoles. In fact, Butler has succeeded in using these bis-(bromoalkyltetrazolyl)-benzenes to generate the tetra-tetrazolemacrocycle (Fig. 1), which include a cavity of variable dimensions tailored by both the length and flexibility of the alkyl chain and also the substitution position on the benzene ring. ${ }^{10-12}$ Furthermore, the X-ray crystal structure of one such macrocycle has been reported. ${ }^{13}$

We have previously reported our initial findings regarding the addition of pendant short-chain alkyl halide arms of some bis-tetrazoles, which yielded not only bis-tetrazole

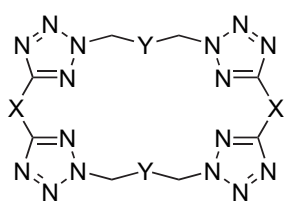

Figure 1. Schematic of tetratetrazole macrocycle with $X=$ substituted benzene and $\mathrm{Y}=$ alkyl chain. 
derivatives with pendant alkyl halide arms but also, and rather surprisingly, bis-tetrazole derivatives with pendant vinyl arms. ${ }^{14}$ The X-ray crystal structure of 1,4-bis(tetrazole)benzene with bromohexyl pendant arms has been reported, but with limited structural and spectroscopic discussion. ${ }^{15}$ In this paper, we report the reactions of 1,4-bis(tetrazole)benzenes with various long chain $\alpha, \omega$-dibromoalkanes and discuss their spectroscopic results. The crystal structures of three derivatives are also presented herein.

\section{Results and discussion}

While alkylation of 5-substituted mono-tetrazole derivatives is known to lead to mixtures of $1-N$ - and $2-N$-substituted products, ${ }^{1}$ the regioselectivity being dependent on the reaction conditions and the nature of the $C$ - and $N$-substituents, the alkylation of bis-tetrazole derivatives can lead to several diverse products. For example, the reaction of 1,2-bis[2-(tributylstannyl)tetrazol-5-yl]benzene $\left(1,2-\left(\mathrm{Bu}_{3} \mathrm{SnN}_{4} \mathrm{C}\right)_{2} \mathrm{C}_{6} \mathrm{H}_{4}\right)$ with 1,2-dibromoethane, reported by Molloy et al., ${ }^{5}$ has been shown to form either a cyclophane or bis(bromoethyltetrazolyl)benzenes, depending on the ratio of the dibromoethane employed in the reaction. When using a 10-fold excess, the cyclophane was obtained; a larger excess (25:1) resulted in the formation of the bis(bromoethyltetrazolyl)benzenes, either the 2-N,2- $N^{\prime}$ - or the 1- $N, 2-N^{\prime}$-isomer, with the $2-N, 2-N^{\prime}$-isomer predominating in a ratio of ca. $3: 1$. We have recently reported the reactions of either $1, n$-bis(tetrazol-5-yl)benzene $\left(1, n\right.$ - $\left.\left(\mathrm{HN}_{4} \mathrm{C}\right)_{2} \mathrm{C}_{6} \mathrm{H}_{4}\right)$ or 1,n-bis[2-(tributylstannyl)tetrazol-5-yl]benzene $\quad\left(1, n-\left(\mathrm{Bu}_{3} \mathrm{SnN}_{4} \mathrm{C}\right)_{2} \mathrm{C}_{6} \mathrm{H}_{4}\right)$ $(n=2,3,4)$ with 1,2-dibromoethane, which yielded compounds containing pendant bromoethyl or vinyl groups with substitution occurring at either $1-N, 2-N^{\prime}$ or $2-N, 2-N^{\prime}$, respectively. ${ }^{14}$

Our strategy was to use both of these approaches, that is, the use of both 1, $n$-bis(tetrazol-5-yl)benzene and 1, $n$-bis[2(tributylstannyl)tetrazol-5-yl]benzene, to obtain sufficient quantities of the 2- $N, 2-N^{\prime}$-isomer of various bis(bromoalkyltetrazolyl)benzenes with a view towards generating derivatised tetra-tetrazole macrocycles. One approach involved the reactions of the 1,4-bis(tetrazole)benzene with long chain $\alpha, \omega$-dibromoalkanes. When the reactions of 1,4-bis(tetrazol5-yl)benzene (1,4-( $\left.\left.\mathrm{HN}_{4} \mathrm{C}\right)_{2} \mathrm{C}_{6} \mathrm{H}_{4}\right)$ with either 1,4-dibromobutane, 1,6-dibromohexane or 1,8-dibromooctane were heated as neat suspensions, no products were obtained and starting materials were recovered in all cases. Furthermore, when the reactions were carried out in the presence of triethylamine in either methanol or toluene with heating to reflux for $24 \mathrm{~h}$, we found that the recovered material, after work-up, contained mainly starting bis-tetrazoles, with approx. $30 \%$ of products. We were able to grow crystals of 1,4-bis[(2-bromohexyl)tetrazol-5-yl]benzene, prepared by this method, which we have already reported. ${ }^{8}$ However, when the reactions of 1,4-bis[2-(tributylstannyl)tetrazol-5yl]benzene $\left(1,4-\left(\mathrm{Bu}_{3} \mathrm{SnN}_{4} \mathrm{C}\right)_{2} \mathrm{C}_{6} \mathrm{H}_{4}\right)$ with either 1,4-dibromobutane, 1,6-dibromohexane or 1,8-dibromooctane were heated as neat suspensions, two products were obtained in relatively high yields, in all the reactions, as well as some recovered starting material (Scheme 1), suggesting that the organotin route was the better method for the synthesis of this particular type of material. It should be pointed out that neither the cyclophane product nor any products containing additions on one ring only were obtained.

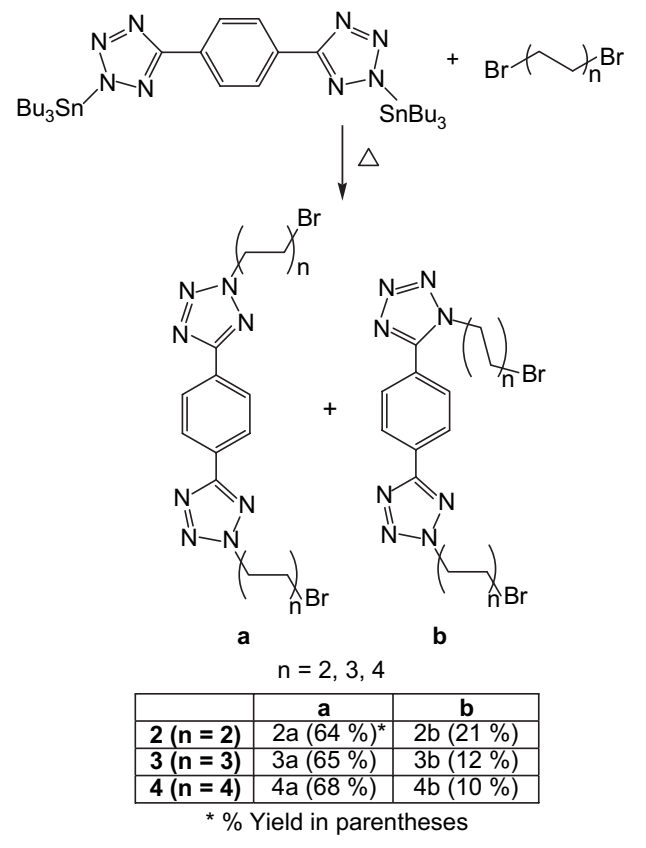

Scheme 1.

Column chromatography, using hexane/ethyl acetate mixtures as eluent, separated the products from the reactants. ${ }^{1} \mathrm{H}$ and ${ }^{13} \mathrm{C}$ NMR spectra were obtained for all samples and revealed that both the 2-N,2- $N^{\prime}$ - and the 1-N,2- $N^{\prime}$-isomers of the bis(bromoalkyltetrazolyl)benzene had formed in the reaction, but the expected cyclophane was not present. The isomeric $2-N, 2-N^{\prime}$ - and $1-N, 2-N^{\prime}$-derivatives are readily distinguishable by their ${ }^{1} \mathrm{H}$ and ${ }^{13} \mathrm{C}$ NMR spectra, ${ }^{5,10,14}$ with the ${ }^{13} \mathrm{C}$ NMR chemical shift of the tetrazole carbon atom appearing at ca. 154.0 and $164.0 \mathrm{ppm}$ in 1,5- and 2,5-disubstituted tetrazoles, respectively. The symmetrical $2-N, 2-N^{\prime}-$ substituted compounds thus gave rise to a single resonance at $164.0 \mathrm{ppm}$ while both signals were apparent in the $1-N$, 2 - $N^{\prime}$-substituted compounds. For example, 1,4-bis[(2-bromobutyl)tetrazol-5-yl]benzene $\left(2-N, 2-N^{\prime}\right)(\mathbf{2 a})$ has a single peak at $164.6 \mathrm{ppm}$ while 1,4-bis[(2-bromobutyl)tetrazol-5yl]benzene $\left(1-N, 2-N^{\prime}\right)$ (2b) has two peaks at 153.8 and $164.0 \mathrm{ppm}$. The main difference in the ${ }^{1} \mathrm{H}$ NMR spectra of the isomers was the doubling of signals in the case of the $1-N, 2-N^{\prime}$-derivatives.

Crystals of compounds $\mathbf{2 a}, \mathbf{2 b}$ and $\mathbf{4 a}$, suitable for an X-ray diffraction study, were obtained from chloroform and the structures confirmed the presence of the pendant bromoalkyl groups at the 2-N,2- $N^{\prime}$-positions for 2a and 4a and at the 1-N,2- $N^{\prime}$-positions for $\mathbf{2 b}$ (Figs. 2, 3 and 4). Table 1 shows important bond lengths and angles for the three structures. We have previously published the structure of $\mathbf{3 a},{ }^{15}$ allowing us to include this also in our comparison of the $2-N, 2-N^{\prime}$ compounds.

The structures of $\mathbf{2 a}, \mathbf{3 a}$ and $\mathbf{4 a}$ exhibit regularity. In each case, the molecular unit is centrosymmetric in the solid state and is sited on a crystallographic inversion centre. The tetrazole rings are essentially coplanar with the benzene ring to 


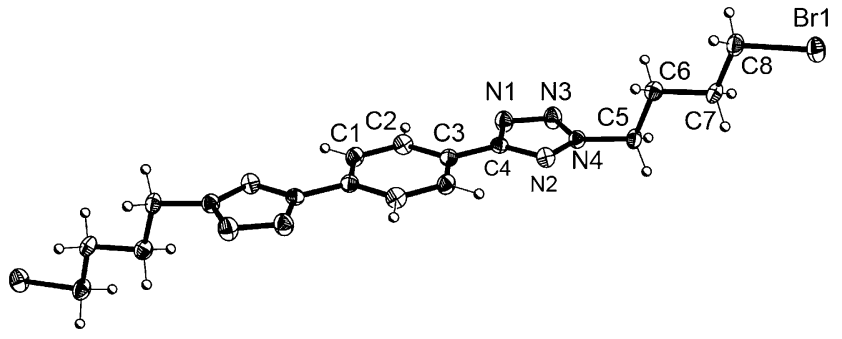

Figure 2. Molecular structure of 2a, showing the labelling scheme for the crystallographically independent atoms. The non-labelled half of the molecule is related to the labelled half by a centre of inversion. Ellipsoids are represented at $50 \%$ probability for non- $\mathrm{H}$ atoms.

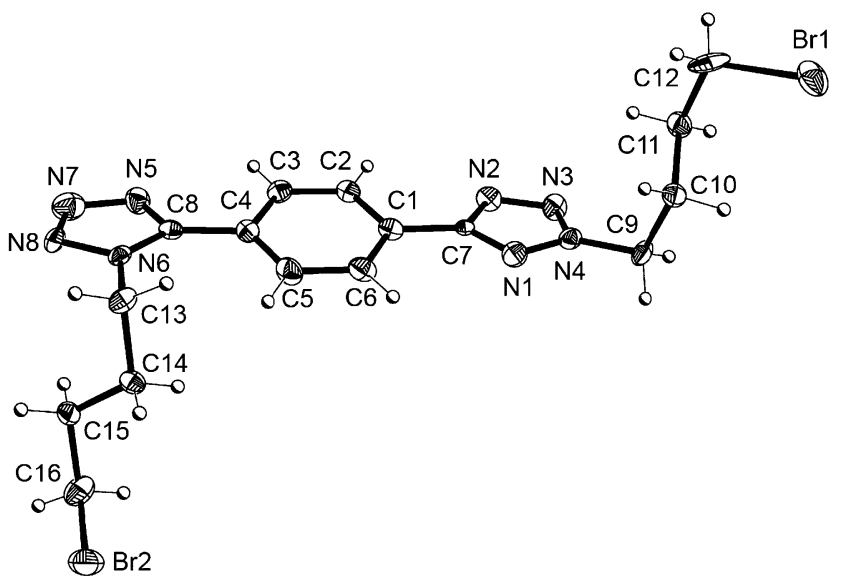

Figure 3. Molecular structure of $\mathbf{2 b}$, showing the labelling scheme used. Ellipsoids are represented at 50\% probability for non- $\mathrm{H}$ atoms.

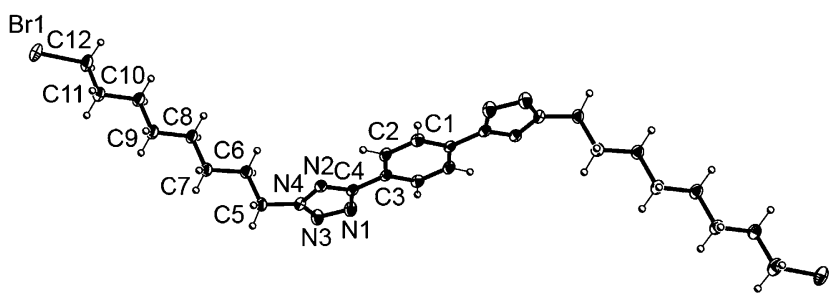

Figure 4. Molecular structure of $\mathbf{4 a}$, showing the labelling scheme for the crystallographically independent atoms. The non-labelled half of the molecule is related to the labelled half by a centre of inversion. Ellipsoids are represented at $50 \%$ probability for non- $\mathrm{H}$ atoms.

which they are attached, and the bromoalkyl groups adopt fully extended conformations, projecting to either side of this plane. The long axes of the alkyl chains form angles of ca. $145^{\circ}$ to the molecular plane (measured by the N4C5-C7 angle in 2a, and equivalent angles in 3a and 4a). Adjacent molecules adopt slipped $\pi$-stacking arrangements, with distances of ca. $3.4 \AA$ between the least squares planes of the molecules, and centroid-centroid separations of ca. $4.6 \AA$ (the lattice parameter $a$ ). The stacks are arranged into 2-D layers so that molecules in adjacent stacks are close to co-planar, introducing relatively short contacts in the range 2.7-2.8 $\AA$ between one $\mathrm{H}$ atom of the first methylene group in the bromoalkyl chain and the $1-\mathrm{N}$ atom of the neighbouring tetrazole rings. The alignment of neighbouring stacks into a 2-D arrangement is consistent with effective lateral packing of the alkyl chains: in each case, the $\mathrm{H}$ atoms of the methylene groups in one chain project into the gaps
Table 1. Selected bond lengths $(\AA)$ and angles $\left(^{\circ}\right)$ for $\mathbf{2 a}, 3 \mathbf{3 a}$ and $\mathbf{4 a}$

\begin{tabular}{llll}
\hline & $\mathbf{2 a}$ & 3a & 4a \\
\hline Bond lengths & & & \\
$\mathrm{C}(1)-\mathrm{C}(2)$ & $1.389(4)$ & $1.389(4)$ & $1.378(3)$ \\
$\mathrm{C}(2)-\mathrm{C}(3)$ & $1.399(4)$ & $1.402(3)$ & $1.395(3)$ \\
$\mathrm{C}(3)-\mathrm{C}(4)$ & $1.477(4)$ & $1.463(3)$ & $1.469(3)$ \\
$\mathrm{C}(4)-\mathrm{N}(1)$ & $1.352(4)$ & $1.356(3)$ & $1.360(3)$ \\
$\mathrm{C}(4)-\mathrm{N}(2)$ & $1.334(4)$ & $1.340(3)$ & $1.323(3)$ \\
$\mathrm{N}(1)-\mathrm{N}(3)$ & $1.324(4)$ & $1.321(3)$ & $1.324(3)$ \\
$\mathrm{N}(3)-\mathrm{N}(4)$ & $1.325(4)$ & $1.333(3)$ & $1.319(3)$ \\
$\mathrm{N}(4)-\mathrm{N}(2)$ & $1.330(3)$ & $1.328(3)$ & $1.329(3)$ \\
$\mathrm{N}(4)-\mathrm{C}(5)$ & $1.472(4)$ & $1.463(3)$ & $1.458(3)$ \\
Bond angles & & & \\
$\mathrm{C}(4)-\mathrm{N}(1)-\mathrm{N}(3)$ & $106.1(3)$ & $106.2(2)$ & $105.7(2)$ \\
$\mathrm{N}(1)-\mathrm{N}(3)-\mathrm{N}(4)$ & $105.9(2)$ & $106.2(2)$ & $106.35(19)$ \\
$\mathrm{N}(3)-\mathrm{N}(4)-\mathrm{N}(2)$ & $114.2(2)$ & $113.8(2)$ & $113.7(2)$ \\
$\mathrm{N}(4)-\mathrm{N}(2)-\mathrm{C}(4)$ & $101.4(3)$ & $102.2(2)$ & $102.1(2)$ \\
$\mathrm{N}(2)-\mathrm{C}(4)-\mathrm{N}(1)$ & $112.4(3)$ & $112.2(2)$ & $112.2(2)$ \\
\hline
\end{tabular}

between methylene groups in the neighbouring chains. The 2-D layer arrangements are effectively identical in each of 2a, 3a and 4a. Adjacent 2-D layers meet so as to bring the terminal $\mathrm{CH}_{2}-\mathrm{Br}$ bonds into an offset co-linear alignment, forming 'Type I' $\mathrm{Br} \cdots \mathrm{Br}$ interactions, as classified previously by Pedireddi et al. ${ }^{16}$ The intermolecular $\mathrm{Br} \cdots \mathrm{Br}$ distances lie in the range 3.4802(4)-3.5351(8) $\AA$, considerably shorter than twice the bromine van der Waals radius $(3.90 \AA)$ and within the range of those values previously reported, 3.415-3.691 $\AA .{ }^{17-20}$

In the crystal structure of $\mathbf{2 b}$, the two tetrazole rings in each molecule are essentially co-planar (rms deviation of 10 fitted atoms $=0.007 \AA$ ), but the plane of the central benzene ring forms a dihedral angle of $9.7(3)^{\circ}$ with this plane. The bromobutyl chains form greater angles to the molecular plane (N4C9-C11 and N6-C13-C15 both ca. 95.5 ), and the terminal $\mathrm{CH}_{2}-\mathrm{Br}$ bond vectors lie perpendicularly close to each other (Fig. 3). The arrangement of the central portions of the molecules in the crystal structure is closely comparable to that in 2a, 3a and 4a. The least-squares planes of the $\pi$-stacked molecules are separated by ca. $3.5 \AA$, with centroid-centroid separations of ca. $4.4 \AA$. Adjacent molecules in the stacks are related by centres of inversion. The molecules in adjacent stacks are again close to co-planar, but with a slightly greater lateral offset along the long axes of the molecules in $\mathbf{2 b}$ compared to $\mathbf{2 a}$. The introduction of a short $\mathrm{H} \cdots \mathrm{H}$ contact (ca. $2.29 \AA$ ) between adjacent benzene rings, and the twisting of these rings from the planes of the tetrazole rings may be attributed at least in part to alleviation of the steric constraints associated with this close contact. The terminal $\mathrm{CH}_{2}-\mathrm{Br}$ bonds again form 'Type I' $\mathrm{Br} \cdots \mathrm{Br}$ interactions, with intermolecular $\mathrm{Br} \cdots \mathrm{Br}$ distances of 3.591(2) and 3.677(2) A. It is noteworthy that while one of these $\mathrm{Br} \cdots$ $\mathrm{Br}$ distances is closely comparable to those in $\mathbf{2 a}, \mathbf{3 a}$ and 4a, the second is significantly longer. This less-than-optimal intermolecular contact presumably contributes to the significantly lower melting point of $\mathbf{2 b}$ (ca. $110^{\circ} \mathrm{C}$ ) compared to the isomeric 2a (ca. $140{ }^{\circ} \mathrm{C}$ ).

\section{Conclusions}

The reactions of 1,4-( $\left(\mathrm{Bu}_{3} \mathrm{SnN}_{4} \mathrm{C}\right)_{2} \mathrm{C}_{6} \mathrm{H}_{4}$ with 1,4-dibromobutane, 1,6-dibromohexane and 1,8-dibromooctane yield compounds containing pendant bromoalkyl groups with 
substitution occurring at either $1-N, 2-N^{\prime}$ or $2-N, 2-N^{\prime}$. The crystal structures of three derivatives were obtained, including both the 1-N,2- $N^{\prime}$ and 2-N,2- $N^{\prime}$-isomers of one derivative. No cyclophane products were observed from any of the reactions. Similar reactions involving 1,3-dibromopropane, 1,5-dibromopentane and 1,7-dibromoheptane are currently being investigated, as are macrocyclic ring closure reactions with 1,4-( $\left(\mathrm{Bu}_{3} \mathrm{SnN}_{4} \mathrm{C}\right)_{2} \mathrm{C}_{6} \mathrm{H}_{4}$ and metal complexation reactions with the resulting macrocyclic ring.

\section{Experimental}

\subsection{General}

${ }^{1} \mathrm{H}$ and ${ }^{13} \mathrm{C}$ NMR $(\delta$ ppm; $J \mathrm{~Hz})$ spectra were recorded on a JOEL JNM-LA300 FT-NMR spectrometer using saturated $\mathrm{CDCl}_{3}$ solutions with $\mathrm{Me}_{4} \mathrm{Si}$ reference, unless indicated otherwise, with resolutions of $0.18 \mathrm{~Hz}$ and $0.01 \mathrm{ppm}$. Infrared spectra $\left(\mathrm{cm}^{-1}\right)$ were recorded as $\mathrm{KBr}$ discs or liquid films between $\mathrm{KBr}$ plates using a Nicolet Impact 410 FT-IR. Melting points were measured with a Stuart Scientific melting point apparatus (SMP1) without correction. Microanalysis was carried out at the Microanalytical Laboratory of University College, Dublin. Standard Schlenk techniques were used throughout.

\subsection{Syntheses}

1,4- $\left(\mathrm{Bu}_{3} \mathrm{SnN}_{4} \mathrm{C}\right)_{2} \mathrm{C}_{6} \mathrm{H}_{4}$ (1) was prepared as described previously. ${ }^{14}$ All other reagents were commercially obtained and used without further purification. Caution: owing to their potentially explosive nature, all preparations of and subsequent reactions with organotin azides and tetrazoles were conducted under an inert atmosphere behind a rigid safety screen.

The numbering scheme for the 1,4-bis-tetrazoles is shown in Figure 5 and all NMR assignments are based on these diagrams.

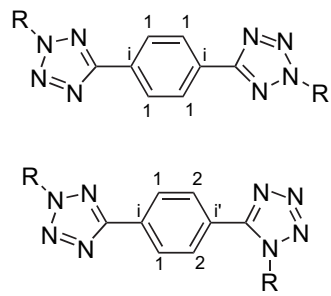

Figure 5. Labelling scheme used for central core in the 1,4-bis(tetrazole) derivatives.

\subsection{General synthesis of compounds}

1,4- $\left(\mathrm{Bu}_{3} \mathrm{SnN}_{4} \mathrm{C}\right)_{2} \mathrm{C}_{6} \mathrm{H}_{4}(\mathbf{1})(10 \mathrm{~g}, 126.2 \mathrm{mmol})$ and the appropriate $\alpha, \omega$-dibromoalkane $(300 \mathrm{mmol})$ were heated to $120^{\circ} \mathrm{C}$ for $24 \mathrm{~h}$, under nitrogen. After cooling, the excess $\alpha, \omega$-dibromoalkane was removed under reduced pressure to afford the mixture of isomers $\mathbf{a}$ and $\mathbf{b}$, as well as some starting bis-tetrazole. These were seperated by column chromatography on silica gel (initially at the ratio of hexane/ ethyl acetate 80:20, followed by the ratio 60:40). All compounds were recrystallised from chloroform.
4.3.1. 1,4-Bis[2-(4-bromobutyl)tetrazol-5-yl]benzene (2$\left.N, 2-N^{\prime}\right)$ (2a). White solid. Anal. Calcd for $\mathrm{C}_{16} \mathrm{H}_{20} \mathrm{Br}_{2} \mathrm{~N}_{8}$ : C, 39.69; H, 4.16; N, 23.14. Found: C, 39.61; H, 4.15; N, 22.85; Yield: 64\%, $3.91 \mathrm{~g}, 8.1 \mathrm{mmol}$; $\nu_{\max }(\mathrm{KBr}) 2958$, $1609,1584,1538,1503,1443,1384,1357,1254,1222$, $1190,1035,1006,875,782,753 \mathrm{~cm}^{-1} ; \mathrm{mp} 138-142{ }^{\circ} \mathrm{C}$; $\delta_{\mathrm{H}}: 1.95\left[\mathrm{~m}, 4 \mathrm{H}, \mathrm{CH}_{2}\right], 2.75\left[\mathrm{~m}, 4 \mathrm{H}, \mathrm{CH}_{2}\right], 3.47[\mathrm{t}, 4 \mathrm{H}$, $\left.J=6.6 \mathrm{~Hz}, \mathrm{CH}_{2} \mathrm{Br}\right], 4.74\left[\mathrm{t}, 4 \mathrm{H}, J=6.6 \mathrm{~Hz}, \mathrm{NCH}_{2}\right], 8.28[\mathrm{~s}$, $\left.4 \mathrm{H}, \mathrm{H}^{1}-\mathrm{C}_{6} \mathrm{H}_{4}\right] ; \delta_{\mathrm{C}}: 27.8\left[\mathrm{CH}_{2}\right], 29.2\left[\mathrm{CH}_{2}\right], 32.2\left[\mathrm{CH}_{2}\right]$, $52.3\left[\mathrm{CH}_{2} \mathrm{~N}\right], 127.3\left[\mathrm{C}^{1}-\mathrm{C}_{6} \mathrm{H}_{4}\right], 129.1\left[\mathrm{i}-\mathrm{C}_{6} \mathrm{H}_{4}\right], 164.6$ $\left[\mathrm{CN}_{4}\right]$.

4.3.2. 1,4-Bis[2-(4-bromobutyl)tetrazol-5-yl]benzene (1$\left.N, 2-N^{\prime}\right)$ (2b). White solid. Anal. Calcd for $\mathrm{C}_{16} \mathrm{H}_{20} \mathrm{Br}_{2} \mathrm{~N}_{8}: \mathrm{C}$, 39.69; H, 4.16; N, 23.14. Found: C, 39.92; H, 4.13; N, 23.04; Yield: $21 \%, 1.28 \mathrm{~g}, 2.6 \mathrm{mmol}$; $\mathrm{mp} 108-112{ }^{\circ} \mathrm{C}$; $\nu_{\max }$ (KBr) 2929, 2853, 1628, 1558, 1538, 1469, 1438, 1370, $1307,1260,1225,1195,1112,1037,1005,847,734$, $645 \mathrm{~cm}^{-1} ; \delta_{\mathrm{H}}: 1.95\left[\mathrm{~m}, 4 \mathrm{H}, \mathrm{CH}_{2}\right], 2.15\left[\mathrm{~m}, 2 \mathrm{H}, \mathrm{CH}_{2}\right], 2.28$ $\left[\mathrm{m}, 2 \mathrm{H}, \mathrm{CH}_{2}\right], 3.40\left[\mathrm{t}, 2 \mathrm{H}, J=6.6 \mathrm{~Hz}, \mathrm{CH}_{2} \mathrm{Br}\right], 3.47[\mathrm{t}, 2 \mathrm{H}, J=$ $\left.6.6 \mathrm{~Hz}, \mathrm{CH}_{2} \mathrm{Br}\right], 4.52\left[\mathrm{t}, 2 \mathrm{H}, J=6.6 \mathrm{~Hz}, \mathrm{~N}^{1} \mathrm{CH}_{2}\right], 4.75[\mathrm{t}, 2 \mathrm{H}$, $\left.J=6.6 \mathrm{~Hz}, \mathrm{~N}^{2} \mathrm{CH}_{2}\right], 7.85\left[\mathrm{~d}, 2 \mathrm{H}, J=6.6 \mathrm{~Hz}, \mathrm{H}^{2}-\mathrm{C}_{6} \mathrm{H}_{4}\right], 8.38$ $\left[\mathrm{d}, 2 \mathrm{H}, J=6.6 \mathrm{~Hz}, \mathrm{H}^{1}-\mathrm{C}_{6} \mathrm{H}_{4}\right] ; \delta_{\mathrm{C}}: 27.8\left[\mathrm{CH}_{2}\right], 28.2\left[\mathrm{CH}_{2}\right]$, $29.1\left[\mathrm{CH}_{2}\right], 29.2\left[\mathrm{CH}_{2}\right], 32.0\left[\mathrm{CH}_{2}\right], 32.1\left[\mathrm{CH}_{2}\right], 47.3$ $\left[\mathrm{CH}_{2} \mathrm{~N}\right], 52.4\left[\mathrm{CH}_{2} \mathrm{~N}\right], 125.5\left[\mathrm{i}-\mathrm{C}_{6} \mathrm{H}_{4}\right], 127.7\left[\mathrm{C}^{1}-\mathrm{C}_{6} \mathrm{H}_{4}\right]$, $129.3\left[\mathrm{C}^{2}-\mathrm{C}_{6} \mathrm{H}_{4}\right], 130.3\left[\mathrm{i}^{\prime}-\mathrm{C}_{6} \mathrm{H}_{4}\right], 153.8\left[\mathrm{CN}_{4}\right], 164.0\left[\mathrm{CN}_{4}\right]$.

4.3.3. 1,6-Bis[2-(6-bromohexyl)tetrazol-5-yl]benzene (2$\left.N, 2-N^{\prime}\right)$ (3a). White solid. Anal. Calcd for $\mathrm{C}_{20} \mathrm{H}_{28} \mathrm{Br}_{2} \mathrm{~N}_{8}$ : C, 44.46; H, 5.22; N, 20.74. Found: C, 44.45; H, 5.20; N, 20.35; Yield: $65 \%, 4.43 \mathrm{~g}, 8.2 \mathrm{mmol}$; mp $104-106{ }^{\circ} \mathrm{C}$; $\nu_{\max }(\mathrm{KBr}) 2931,2862,1610,1580,1543,1515,1449$, 1396, 1352, 1293, 1250, 1182, 1150, 1082, 1041, 897, $783,756 \mathrm{~cm}^{-1} ; \delta_{\mathrm{H}}: 1.40\left[\mathrm{~m}, 4 \mathrm{H}, \mathrm{CH}_{2}\right], 1.55\left[\mathrm{~m}, 4 \mathrm{H}, \mathrm{CH}_{2}\right]$, $1.88\left[\mathrm{~m}, 4 \mathrm{H}, \mathrm{CH}_{2}\right], 2.11\left[\mathrm{~m}, 4 \mathrm{H}, \mathrm{CH}_{2}\right], 3.41[\mathrm{t}, 4 \mathrm{H}$, $J=6.6 \mathrm{~Hz}, \mathrm{CH}_{2} \mathrm{Br}$ ], $4.69\left[\mathrm{t}, 4 \mathrm{H}, J=6.6 \mathrm{~Hz}, \mathrm{NCH}_{2}\right], 8.28[\mathrm{~s}$, $\left.4 \mathrm{H}, \mathrm{H}^{1}-\mathrm{C}_{6} \mathrm{H}_{4}\right] ; \delta_{\mathrm{C}}: 25.6\left[\mathrm{CH}_{2}\right], 27.5\left[\mathrm{CH}_{2}\right], 29.2\left[\mathrm{CH}_{2}\right]$, $32.4\left[\mathrm{CH}_{2}\right], 33.5\left[\mathrm{CH}_{2}\right], 53.1\left[\mathrm{CH}_{2} \mathrm{~N}\right], 127.3\left[\mathrm{C}^{1}-\mathrm{C}_{6} \mathrm{H}_{4}\right]$, $129.1\left[\mathrm{i}-\mathrm{C}_{6} \mathrm{H}_{4}\right], 164.5\left[\mathrm{CN}_{4}\right]$.

4.3.4. 1,6-Bis[2-(6-bromohexyl)tetrazol-5-yl]benzene (1$\left.N, 2-N^{\prime}\right)(3 b)$. White solid. Anal. Calcd for $\mathrm{C}_{20} \mathrm{H}_{28} \mathrm{Br}_{2} \mathrm{~N}_{8}$ : C, 44.46; H, 5.22; N, 20.74. Found: C, 44.40; H, 5.20; N, 20.45; Yield: $12 \%, 0.82 \mathrm{~g}, 1.5 \mathrm{mmol}$; mp 84-86 ${ }^{\circ} \mathrm{C}$; $\nu_{\max }$ (KBr) 2930, 2865, 1625, 1550, 1538, 1470, 1436, 1379, $1316,1262,1224,1195,1110,1036,1015,846,734$, $649 \mathrm{~cm}^{-1} ; \delta_{\mathrm{H}}: 1.46\left[\mathrm{~m}, 4 \mathrm{H}, \mathrm{CH}_{2}\right], 1.84\left[\mathrm{~m}, 4 \mathrm{H}, \mathrm{CH}_{2}\right], 2.05$ $\left[\mathrm{m}, 8 \mathrm{H}, \mathrm{CH}_{2}\right], 3.36\left[\mathrm{t}, 2 \mathrm{H}, J=6.6 \mathrm{~Hz}, \mathrm{CH}_{2} \mathrm{Br}\right], 3.41[\mathrm{t}, 2 \mathrm{H}, J=$ $\left.6.6 \mathrm{~Hz}, \mathrm{CH}_{2} \mathrm{Br}\right], 4.51\left[\mathrm{t}, 2 \mathrm{H}, J=6.6 \mathrm{~Hz}, \mathrm{~N}^{1} \mathrm{CH}_{2}\right], 4.70[\mathrm{t}, 2 \mathrm{H}$, $\left.J=6.6 \mathrm{~Hz}, \mathrm{~N}^{2} \mathrm{CH}_{2}\right], 7.84\left[\mathrm{~d}, 2 \mathrm{H}, J=6.6 \mathrm{~Hz}, \mathrm{H}^{2}-\mathrm{C}_{6} \mathrm{H}_{4}\right], 8.32$ $\left[\mathrm{d}, 2 \mathrm{H}, J=6.6 \mathrm{~Hz}, \mathrm{H}^{1}-\mathrm{C}_{6} \mathrm{H}_{4}\right] ; \delta_{\mathrm{C}}: 25.3\left[\mathrm{CH}_{2}\right], 25.4\left[\mathrm{CH}_{2}\right]$, $27.1\left[\mathrm{CH}_{2}\right], 27.2\left[\mathrm{CH}_{2}\right], 28.9\left[\mathrm{CH}_{2}\right], 29.3\left[\mathrm{CH}_{2}\right], 32.1$ $\left[\mathrm{CH}_{2}\right], 32.2\left[\mathrm{CH}_{2}\right], 33.3\left[\mathrm{CH}_{2}\right], 33.4\left[\mathrm{CH}_{2}\right], 47.9\left[\mathrm{CH}_{2} \mathrm{~N}\right]$, $53.0\left[\mathrm{CH}_{2} \mathrm{~N}\right], 125.5\left[\mathrm{i}-\mathrm{C}_{6} \mathrm{H}_{4}\right], 127.7\left[\mathrm{C}^{1}-\mathrm{C}_{6} \mathrm{H}_{4}\right], 129.3\left[\mathrm{C}^{2}-\right.$ $\left.\mathrm{C}_{6} \mathrm{H}_{4}\right], 130.3\left[\mathrm{i}^{\prime}-\mathrm{C}_{6} \mathrm{H}_{4}\right], 153.8\left[\mathrm{CN}_{4}\right], 164.1\left[\mathrm{CN}_{4}\right]$.

4.3.5. 1,8-Bis[2-(8-bromooctyl)tetrazol-5-yl]benzene (2$\left.N, 2-N^{\prime}\right)(4 a)$. White solid. Anal. Calcd for $\mathrm{C}_{24} \mathrm{H}_{36} \mathrm{Br}_{2} \mathrm{~N}_{8}: \mathrm{C}$, 48.33; H, 6.08; N, 18.79. Found: C, 47.95; H, 6.08; N, 18.48; Yield: $68 \%, 5.12 \mathrm{~g}, 8.6 \mathrm{mmol} ; \mathrm{mp} \mathrm{88-94}{ }^{\circ} \mathrm{C} ; \nu_{\max }$ (KBr) 2929, 2852, 1629, 1557, 1468, 1430, 1354, 1357, $1266,1226,1198,1048,1006,854,744,723,647 \mathrm{~cm}^{-1} ; \delta_{\mathrm{H}}$ : $1.39\left[\mathrm{~m}, 16 \mathrm{H}, \mathrm{CH}_{2}\right], 1.85\left[\mathrm{~m}, 4 \mathrm{H}, \mathrm{CH}_{2}\right], 2.08$ [m, 4H, $\left.\mathrm{CH}_{2}\right]$, 
$3.39\left[\mathrm{t}, 4 \mathrm{H}, J=6.6 \mathrm{~Hz}, \mathrm{CH}_{2} \mathrm{Br}\right], 4.67\left[\mathrm{t}, 4 \mathrm{H}, J=6.6 \mathrm{~Hz}, \mathrm{NCH}_{2}\right]$, $8.28\left[\mathrm{~s}, 4 \mathrm{H}, \mathrm{H}^{1}-\mathrm{C}_{6} \mathrm{H}_{4}\right] ; \delta_{\mathrm{C}}: 26.3\left[\mathrm{CH}_{2}\right], 27.9\left[\mathrm{CH}_{2}\right], 28.5$ $\left[\mathrm{CH}_{2}\right], 28.7\left[\mathrm{CH}_{2}\right], 29.3\left[\mathrm{CH}_{2}\right], 32.7\left[\mathrm{CH}_{2}\right], 33.9\left[\mathrm{CH}_{2}\right]$, $53.3\left[\mathrm{CH}_{2} \mathrm{~N}\right], 127.3\left[\mathrm{C}^{1}-\mathrm{C}_{6} \mathrm{H}_{4}\right], 129.1\left[\mathrm{i}-\mathrm{C}_{6} \mathrm{H}_{4}\right], 164.5\left[\mathrm{CN}_{4}\right]$.

4.3.6. 1,8-Bis[2-(8-bromooctyl)tetrazol-5-yl]benzene (1$\left.N, \mathbf{2}-N^{\prime}\right)$ (4b). White solid. Anal. Calcd for $\mathrm{C}_{24} \mathrm{H}_{36} \mathrm{Br}_{2} \mathrm{~N}_{8}: \mathrm{C}$, 48.33; H, 6.08; N, 18.79. Found: C, 48.16; H, 6.07; N, 18.58; Yield: $10 \%, 0.75 \mathrm{~g}, 1.3 \mathrm{mmol} ; \mathrm{mp} 64-68^{\circ} \mathrm{C}$; $\nu_{\max }$ (KBr) 2929, 2853, 1626, 1550, 1538, 1469, 1434, 1378, 1303, 1271, 1226, 1197, 1112, 1044, 1003, 848, 736, $645 \mathrm{~cm}^{-1} ; \delta_{\mathrm{H}}: 1.29\left[\mathrm{~m}, 8 \mathrm{H}, \mathrm{CH}_{2}\right], 1.37\left[\mathrm{~m}, 8 \mathrm{H}, \mathrm{CH}_{2}\right], 1.82$ $\left[\mathrm{m}, 4 \mathrm{H}, \mathrm{CH}_{2}\right], 1.95\left[\mathrm{~m}, 2 \mathrm{H}, \mathrm{CH}_{2}\right], 2.09\left[\mathrm{~m}, 2 \mathrm{H}, \mathrm{CH}_{2}\right], 3.38$ $\left[\mathrm{t}, 2 \mathrm{H}, J=6.6 \mathrm{~Hz}, \mathrm{CH}_{2} \mathrm{Br}\right], 3.40\left[\mathrm{t}, 2 \mathrm{H}, J=6.6 \mathrm{~Hz}, \mathrm{CH}_{2} \mathrm{Br}\right.$, $4.46\left[\mathrm{t}, 2 \mathrm{H}, J=6.6 \mathrm{~Hz}, \mathrm{~N}^{1} \mathrm{CH}_{2}\right], 4.69[\mathrm{t}, 2 \mathrm{H}, J=6.6 \mathrm{~Hz}$, $\mathrm{N}^{2} \mathrm{CH}_{2}$ ], 7.82 [d, 2H, $J=6.6 \mathrm{~Hz}, \mathrm{H}^{2}-\mathrm{C}_{6} \mathrm{H}_{4}$ ], 8.36 [d, $2 \mathrm{H}, J=$ $\left.6.6 \mathrm{~Hz}, \mathrm{H}^{1}-\mathrm{C}_{6} \mathrm{H}_{4}\right] ; \delta_{\mathrm{C}}: 26.2\left[\mathrm{CH}_{2}\right], 26.3\left[\mathrm{CH}_{2}\right], 27.9\left[\mathrm{CH}_{2}\right]$, $28.0\left[\mathrm{CH}_{2}\right], 28.4\left[\mathrm{CH}_{2}\right], 28.5\left[\mathrm{CH}_{2}\right], 28.7\left[\mathrm{CH}_{2}\right], 29.3\left[\mathrm{CH}_{2}\right]$, $29.7\left[\mathrm{CH}_{2}\right], 32.6\left[\mathrm{CH}_{2}\right], 32.7\left[\mathrm{CH}_{2}\right], 33.8\left[\mathrm{CH}_{2}\right], 48.2$ $\left[\mathrm{CH}_{2} \mathrm{~N}\right], 53.4\left[\mathrm{CH}_{2} \mathrm{~N}\right], 125.7\left[\mathrm{i}-\mathrm{C}_{6} \mathrm{H}_{4}\right], 127.6\left[\mathrm{C}^{1}-\mathrm{C}_{6} \mathrm{H}_{4}\right]$, $129.3\left[\mathrm{C}^{2}-\mathrm{C}_{6} \mathrm{H}_{4}\right], 130.3\left[\mathrm{i}^{\prime}-\mathrm{C}_{6} \mathrm{H}_{4}\right], 153.8\left[\mathrm{CN}_{4}\right], 163.8\left[\mathrm{CN}_{4}\right]$.

\subsection{X-ray crystallography}

Suitable crystals of $\mathbf{2 a}, \mathbf{2 b}$ and $\mathbf{4 a}$ for X-ray study were obtained by recrystallisation from chloroform solutions. Data were collected at 180(2) K on a Bruker Nonius X8 APEX II diffractometer, ${ }^{21}$ and a multi-scan correction was applied. ${ }^{22}$ The structures were refined against $F^{2}$ using all data. ${ }^{23}$ Hydrogen atoms were placed at calculated positions and refined using a riding model.

4.4.1. Compound 2a. Crystal data: $\mathrm{C}_{16} \mathrm{H}_{20} \mathrm{Br}_{2} \mathrm{~N}_{8}$, $M=484.22$, triclinic, $a=4.5722(7), \quad b=5.8805(9), \quad c=$ 18.119(3) $\AA$, $\alpha=96.943(6), \beta=96.426(6), \gamma=101.287(6)^{\circ}$, $U=469.61(13) \AA^{3}$, space group $P 1, Z=1, \mu(\mathrm{Mo}-\mathrm{K} \alpha)=$ $4.334 \mathrm{~mm}^{-1} .7346$ data (1717 unique, $\left.R_{\text {int }}=0.0386\right)$ were measured in the range $3.59<\theta<25.74^{\circ} . R_{1}(I>2 \sigma(I))=$ 0.0321 and $w R_{2}$ (all data $)=0.0815$. Goodness of fit on $F^{2}=1.06$. CCDC No. 604247 .

4.4.2. Compound 2b. Crystal data: $\mathrm{C}_{16} \mathrm{H}_{20} \mathrm{Br}_{2} \mathrm{~N}_{8}$, $M=484.22$, triclinic, $a=6.7256(14), \quad b=8.1427(19), \quad c=$ 17.186(4) $\AA$, $\alpha=96.972(8), \quad \beta=92.193(8), \quad \gamma=90.034(8)^{\circ}$, $U=933.5(4) \AA^{3}$, space group $P 1, \quad Z=2, \quad \mu(\mathrm{Mo}-\mathrm{K} \alpha)=$ $4.361 \mathrm{~mm}^{-1}$. 11127 data (3428 unique, $R_{\mathrm{int}}=0.0607$ ) were measured in the range $3.59<\theta<25.84^{\circ} . R_{1}(I>2 \sigma(I))=$ 0.0906 and $w R_{2}$ (all data $)=0.2519$. Goodness of fit on $F^{2}=1.04$. CCDC No. 604248 .

4.4.3. Compound 4a. Crystal data: $\mathrm{C}_{24} \mathrm{H}_{36} \mathrm{Br}_{2} \mathrm{~N}_{8}$, $M=596.43$, triclinic, $a=4.6665(5), \quad b=5.6593(5), \quad c=$ 25.284(2) $\mathrm{\AA}, \alpha=92.812(3), \beta=90.773(4), \gamma=102.138(3)^{\circ}$, $U=651.82(10) \AA^{3}$, space group $P 1, Z=1, \mu(\mathrm{Mo}-\mathrm{K} \alpha)=$ $3.138 \mathrm{~mm}^{-1}$. 11318 data $\left(2448\right.$ unique, $\left.R_{\text {int }}=0.0477\right)$ were measured in the range $3.69<\theta<25.84^{\circ} . R_{1}(I>2 \sigma(I))=0.0338$ and $w R_{2}$ (all data) $=0.0863$. Goodness of fit on $F^{2}=1.04$. CCDC No. 604249.

\subsection{Crystallographic data}

Crystallographic data for $\mathbf{2 a}, \mathbf{2 b}$ and $\mathbf{4 a}$ have been deposited with the Cambridge Crystallographic Data Centre. Copies of this information may be obtained free of charge from deposit@ccdc.cam.ac.uk or www: http://www.ccdc.cam.ac.uk.

\section{Acknowledgements}

We would like to thank the Postgraduate R\&D Skills programme (Technological Sector Research, Strand III, Project Code CRS01/TA02) for financial assistance, and Drs. B. Creaven and B. A. Murray for useful discussions. A.D.B. is grateful to the Danish Natural Sciences Research Council and the Carlsberg Foundation for provision of the X-ray equipment.

\section{References and notes}

1. Butler, R. N. Comprehensive Heterocyclic Chemistry; Katritzky, A. R., Rees, C. W., Scriven, E. F. V., Eds.; Permagon: Oxford, UK, 1996; Vol. 4.

2. Herr, R. J. Bioorg. Med. Chem. 2002, 10, 3379.

3. Sisido, K.; Nabika, K.; Isida, T.; Kozima, S. J. Organomet. Chem. 1971, 33, 337.

4. Hill, M.; Mahon, M. F.; McGinley, J.; Molloy, K. C. J. Chem. Soc., Dalton Trans. 1996, 835.

5. Bethel, P. A.; Hill, M. S.; Mahon, M. F.; Molloy, K. C. J. Chem. Soc., Perkin Trans. 1 1999, 3507.

6. Demko, Z. P.; Sharpless, K. B. J. Org. Chem. 2001, 66, 7945.

7. Stassen, A. F.; Kooijman, H.; Spek, A. L.; Haasnoot, J. G.; Reedijk, J. J. Chem. Crystallogr. 2001, 31, 307.

8. Stassen, A. F.; Grunert, M.; Mills, A. M.; Spek, A. L.; Haasnoot, J. G.; Reedijk, J.; Linert, W. Dalton Trans. 2003, 3628.

9. Wu, T.; Yi, B.-H.; Li, D. Inorg. Chem. 2005, 44, 4130.

10. Butler, R. N.; Fleming, A. F. M. J. Heterocycl. Chem. 1997, 34 , 691.

11. Butler, R. N.; Quinn, K. F.; Welke, B. J. Chem. Soc., Chem. Commun. 1992, 1481.

12. Butler, R. N.; Ní Bhrádaigh, E. P. J. Chem. Res. Synop. 1994, 148.

13. Butler, R. N.; McGinley, J.; Mahon, M. F.; Molloy, K. C.; Ní Bhrádaigh, E. P. Acta Crystallogr. 2001, E57, 195.

14. Fleming, A.; Kelleher, F.; Mahon, M. F.; McGinley, J.; Prajapati, V. Tetrahedron 2005, 61, 7002.

15. Fleming, A. F. M.; Kelleher, F.; Mahon, M. F.; McGinley, J.; Molloy, K. C.; Prajapati, V. Acta Crystallogr. 2004, E60, 2388.

16. Pedireddi, V. R.; Reddy, D. S.; Satish Goud, B.; Craig, D. C.; Rae, A. D.; Desiraju, G. J. Chem. Soc., Perkin Trans. 2 1994, 2353.

17. Christofi, A. M.; Garratt, P. J.; Hogarth, G.; Steed, J. W. J. Chem. Soc., Dalton Trans. 2000, 2137.

18. Kuhn, N.; Abu-Rayyan, A.; Eichele, K.; Schwarz, S.; Steinmann, M. Inorg. Chim. Acta 2004, 357, 1799.

19. Ruthe, F.; Du Mont, W.-W.; Jones, P. G. Chem. Commun. 1997, 1947.

20. Savinsky, R.; Hopf, H.; Dix, I.; Jones, P. G. Eur. J. Org. Chem. 2001, 4595.

21. Bruker Nonius. APEX2. Version 1.0-22; Bruker Nonius BV: Delft, The Netherlands, 2004.

22. Sheldrick, G. M. SADABS. Version 2.10; Bruker AXS: Madison, Wisconsin, USA, 2003.

23. Sheldrick, G. M. SHELXTL. Version 6.10; Bruker AXS: Madison, Wisconsin, USA, 2000. 